\title{
ANALYSIS OF THE PREVAILING FACTORS OF THE ENTERPRISE FINANCING STRUCTURE
}

\author{
VINTILA, G[eorgeta] \& NEDELESCU, D[umitru] M[ihai]
}

\begin{abstract}
Determining an optimal financing structure is one of the managers' main objectives and at the same time problem which is difficult to be solved at a practical level. By means of econometric instruments, this study tried to identify that theoretical model based on classical and modern theories it is suitable to adopt an optimal financing structure of the enterprise. Starting from these facts, the empirical analysis has as object the financial data from companies listed at Bucharest Stock Exchange (BVB). The results obtained using the multiple linear regression and the method of main components reflect the fact that the variables taken into consideration explain in a great measure that the best structure of the enterprise capital could be fulfilled according to the principles of the pecking order theory only if we minimize the the weighted average cost of the capital (CMP), which is significantly influenced by the financial leverage $(L E V)$, weight of fixed assets in the total assets (PAI) and return on equity (ROE).

Keywords: capital structure, average cost of the capital, pecking order theory, financial structure
\end{abstract}

\section{INTRODUCTION}

When talking of enterprises, capitals are fewer and fewer, more and more expensive, and, in a context of strong competence, the expected profit is obtained with more difficulty, taking greater risks which are hard to anticipate and diminish [6]. For an enterprise to enjoy financial balance, it must ensure an optimal capital structure, which is unfortunately ,easy to prescribe, but difficult to achieve and which has as main objective the minimization of the financing cost [7].

Over the time, the capital structure of companies and their preferences in the choice of their activities financing were the subject of multiples studies for economists.

We have chosen this subject because we belive that by investigating how companies are raising capital, but also taking into the cost of these financial sources, is valuable information for investors, while understanding it can bring additional knowledge about its influence over the corporate performance. As for the financial structure, literature has debated multiple theories which finally materialized in a series of financial models: the classical theory of the capital structure, the compromise theory, the agent theory and the pecking order theory.

We have considered several models regarding the capital structure of companies, trying to understand their applicability to those that activate in Romania.

The pecking order theory caught the attention of several economists famous for their contribution to the financial theory and practice. They deeloped a series of models that can be grouped in line with the objectives targeted by the enterprise management, as it follows in table 1 .

\section{MODELS BASED ON THE PECKING ORDER THEORY ON THE INFLUENTIAL FACTORS OF THE CAPITAL STRUCTURE}

Contrary to the previous theories, the pecking order theory is not centered on the optima financial structure concept, but it does not exclude it either.

We can inquire on the one hand whether an enterprise makes the best financial decision by setting a top of the financing methods for an investment, that is whether it chooses the best financing means combination and, on the other hand, we can inquire if applying the the pecking order principle would not lead to a different deffinition of the optimal financial structure while targeting the same objective (the best indebtnessrate degree).

According to this theory, there is no well-defined financial structure, there is only the idea of internal capital (the most utilized) and external capital (utilized only when strictly necessary).ne of the explanations regarding the financial behaviour of the enterprise based on the pecking order theory consists of the existence of taxes and transaction costs which favour the profit reinvestment and calling for debts rather than for shares issuance.

Therefore, the divided tax, as well as the shareholders' income tax, influence the financing decision, shareholders prefering profit reinvestment rather than dividend collection whereas dividend tax is bigger than shareholders' income tax.

Deductibility of expenses with interests within the net profit of profitable companies and generating fiscal economies also encourage a constantly larger usage of debts when compared to capital raising through shares issuance.

In conclusion, we can say that enterprises usually avoid releasing shares issuance on the capital market and does not contract loans only in cases where the investment plan calims the increase of the fund limit to a superior level of the current cash-flows. This way, managers try to stay away of the financing market discipline.

The empirical evidences hepled us in seeking to indentify some indicators that we had used in the case study. These are studies of the autors Donaldson (1961), Myers (1984), Myers and Majluf (1984), Narayanan 
(1988), Harris and Raviv (1991), Fama and Jensen (1985), Williamson (1988) and Hyafil (1993). (table 1)

\begin{tabular}{|c|c|}
\hline \multicolumn{2}{|r|}{ Pecking order theory based models } \\
\hline $\begin{array}{c}\text { Donaldson } \\
(1961)\end{array}$ & $\begin{array}{l}\text { According to this model, enterprises avoid shares } \\
\text { issuances and do not borrow unless the investment } \\
\text { claims superior funds. Thus, managers wish to stay } \\
\text { away of the financing market discipline. Donaldson } \\
\text { indirectly highlighted the existence of a resource top: } \\
\text { self-financing, long term loan and capital increase. }\end{array}$ \\
\hline $\begin{array}{l}\text { Myers } \\
(1984)\end{array}$ & $\begin{array}{l}\text { Myers creates an analysis comparative to the } \\
\text { compromise theory and the pecking order theory and } \\
\text { the impact of the financing according to thsi model, } \\
\text { there is no well-defined financing structure, there is } \\
\text { only the idea of internal capital (the most utilized) } \\
\text { and external capital (utilized only when strictly } \\
\text { necessary) [4]. }\end{array}$ \\
\hline $\begin{array}{r}\text { Myc } \\
\text { Ma } \\
(19\end{array}$ & $\begin{array}{l}\text { This model contains the following behaviour } \\
\text { hypotheses: the manager acts in the current } \\
\text { shareholders' interest; the existing shareholders are } \\
\text { not active and do not affect the efficiency of the } \\
\text { decisions made by the manager; the new sahreholders } \\
\text { are no informed on the mathematical hope of the old } \\
\text { shareholders' title values. The manager is forced to } \\
\text { stop making an effective investment which would } \\
\text { result in a decrease of the enterprise value. } \\
\text { According to Myers-Majluf, achieving capital increase } \\
\text { is an unfavourable sign for a non-performing } \\
\text { enterprise. }\end{array}$ \\
\hline $\begin{array}{c}\text { Narayanan } \\
(\mathbf{1 9 8 8 )}\end{array}$ & $\begin{array}{l}\text { Narayanan shows that the market cannot assess the } \\
\text { true value of enterprises. Consequently, a non-profit } \\
\text { enterprise can be financing thans to market } \\
\text { malfunctions. He proves that a profitable enterprise, in } \\
\text { order to hightlight its true value, is interested in } \\
\text { financing the investment by indebtness rather than by } \\
\text { capital increase. The managers seek to enrich the } \\
\text { existent shareholders. Investors do not know the } \\
\text { investment opportunities and assess them at an } \\
\text { average value considering the financing alternative } \\
\text { that was chosen. Capital increase is a sign of an } \\
\text { unfavourable situation [5]. }\end{array}$ \\
\hline $\begin{array}{l}\text { Harris- } \\
\text { Raviv } \\
\text { (1991) }\end{array}$ & $\begin{array}{l}\text { Harris-Raviv highlights that the „fully revealing” } \\
\text { balance of signaling is achieved by the hypothesis } \\
\text { describing the Myers-Majluf model while considering } \\
\text { that ,imitation” is not interesting [3]. }\end{array}$ \\
\hline \multicolumn{2}{|c|}{$\begin{array}{l}\text { Models of selecting financing contracts with the aim of cost } \\
\text { reduction }\end{array}$} \\
\hline $\begin{array}{l}\text { Fama- } \\
\text { Jensen } \\
(\mathbf{1 9 8 5})\end{array}$ & $\begin{array}{l}\text { Fama-Jensen shows how the financial structure is } \\
\text { indirectly defined by fixed costs minimization. Fixed } \\
\text { costs have a significat weight in the total costs and the } \\
\text { enterprise surviving depends on the its capacity of } \\
\text { reducing them. Fama considers that the financial } \\
\text { structure will be less debted if the selling value of the } \\
\text { assets is decreased. If such is the case, the enterprise } \\
\text { will achieve a financial structure where the own funds } \\
\text { financing prevails, or by analysing the incremental } \\
\text { costs advantages of different financing resources } \\
\text { (compromise between financing where indebtnes } \\
\text { swould have larger costs thatn advantages) [2]. }\end{array}$ \\
\hline $\begin{array}{l}\text { Williamson } \\
\text { (1988) }\end{array}$ & $\begin{array}{l}\text { Williamson comes with the argument of investment } \\
\text { "specificity". His approach is different of Fama's in } \\
\text { that he does not study the financial structure that } \\
\text { allows the cost reduction coming from contracts } \\
\text { between the enterprise and its partners. He assumes } \\
\text { that contract parties have a limtied rationality. } \\
\text { Williamson concludes that indebtnessand capital } \\
\text { increase are not considered the sole financing } \\
\text { resources [8]. }\end{array}$ \\
\hline $\begin{array}{l}\text { Hyafil } \\
(1993)\end{array}$ & $\begin{array}{l}\text { Hyafil labels this management structure as flexible: in } \\
\text { case problems appear, the shareholders cand decide } \\
\text { whether the enterprise should be liquidated or if } \\
\text { measures of financial recovery shall be applied. } \\
\text { Instead, indebtnessdoes not allow the ex-post } \\
\text { adjustment at the same level. If there is a specific } \\
\text { investment, the investors will want to take advantage } \\
\text { of one of these weaknesses, thus adjusting the } \\
\text { transaction price. As a more simple financing } \\
\text { structure, indebtnessshall be more expensive and, } \\
\text { thus, better adapted. }\end{array}$ \\
\hline
\end{tabular}

Tab. 1. Models based on pecking order theory

\section{EMPIRICAL STUDY ON THE INFLUENTIAL FACTORS OF THE CAPITAL STRUCTURE}

Empirical studies analysing the capital structure of publicly traded corporation are grouped based on the national economy type: fully developed economies and developing economies. As for developing economy countries, a series of experts (Booth, Aivazian, Demirguc-Kunt, Maksimovic, 2001) who analysed the capital structure in 10 developing countries remarked that the influencial factors listed above are also relevant for these countries despite the significatn differences between the two categories of economies [1].

While striking to determine an optimal level of the financial structure, representing one of the main ojectives of managers and, at the same time, a difficult problem to solve in practice, we consider that the optimal financial can be reached by developing an econometric model whose dependent variable can be: the weighted average cost of the capital (CMP) [6].

The empirical analysis has as object the financial data from companies listed at Bucharest Stock Exchange (BVB) and was made by a multiple regression model who analysed the influence of six independent factors on the weighted average cost of the capital (CMP):

- financial leverage (LEV);

- weight of fixed assets in the total assets (PAI);

- rate of financial autonomy (RAF);

- debts rate (RDAT);

- return on assets (ROA);

- return on equity (ROE).

As a result, the dependent variable will be expressed as it follows:

$$
\begin{aligned}
& C M P=\alpha_{0}+\alpha_{1} \frac{D A T}{K_{P R}}+\alpha_{2} \frac{A I}{A T}+\alpha_{3} \frac{K_{P R}}{K_{P E R}}+\alpha_{4} \frac{D A T}{A T}+\alpha_{5} \frac{R E}{A T}+ \\
& \alpha_{6} \frac{R E}{K_{P R}}
\end{aligned}
$$

Statistically from the elimination process of the insignificant factors towards the dependent variable CMP we may conclude that only the probability value ( $\mathrm{P}$ value) of the parameters: financial leverage LEV, weight of fixed assets in the total assets PAI and return on equity ROE is smaller than 0.01 .

Thus, all the regression parameters are insignificant statistically with the exception of the independent variables, financial leverage LEV, weight of fixed assets in the total assets PAI and return on equity ROE which have an important influence on the dependent variable CMP (table 2).

In order to decide if the model is valid we will see the value of F-statistic and Prob (F-statistic). As the probability of the test $\mathrm{F}$ (Prob (F-statistic)) is 0.000000 and smaller than $1 \%$ we may say that the regression model is valid and can be used for the analysis of the dependence between the weighted average cost of the capital (CMP) and the independent variables of the model.

\begin{tabular}{|c|c|}
\hline R-squared & 0.669540 \\
\hline Adjusted R-squared & 0.651837 \\
\hline F-statistic & 37.82023 \\
\hline
\end{tabular}




\begin{tabular}{l} 
Prob(F-statistic) \\
\hline Durbin-Watson stat \\
Tab. 2. The validation of the model
\end{tabular}

R-squared Coefficient $R^{2}$ is 0.669540 and proves the determinative grade used to show how the regression model explains the dependence between variables. Thus, approx. $66.95 \%$ of the weighted average cost of the capital variation (CMP) is explained by the parameters variation used in the regression model, namely the value of the coefficient $\mathrm{R}^{2}$ shows a very low degree in explicating the model. Adjusted R-squared is 0.651837 . The values calculated for R-squared and Adjusted Rsquared for a regression model should show the following relation: $R^{2}$ ajustated $\leq R^{2}$. For the analysed regression model the value of the Adjusted R-squared is in accordance with the conclusions drawn from the analysis of $\mathrm{R}^{2}$. We may consider that the Adjusted Rsquared assures a higher precision than R-squared.If the Adjusted R-squared is significantly smaller than Rsquared it means that certain explicit variables are missing and without these ones the dependent variable is not completely measured and this is not relevant in our case because the difference between them is very low 0.017703.As a result of Durbin-Watson test for the residues' autocorrelation we get a value of 1.897618 (being between 1.8-2.2) which means that between the residues there is no correlation. In the figure 1 we presented the way in which the analyzed regression residues are distributed and we may notice that the residues values have a constant distribution, being dispersed and auto correlated.

The Hypothesis testing is checked by the Jarque-Bera test. The test measures the difference between the asymmetrical coefficient and the analyzed distribution kurtosis with the normal distribution. Thus, if the probability of the test is higher than the chosen relevant level then the zero hypothesis is accepted. For a normal distribution: the skewness coefficient is 0.651765 , meaning that the normal distribution is symmetrical and the kurtosis is 2.974380 . If the value of this indicator is smaller than 3 then the distribution is called platikurtosis.

According to the results of this model the distribution CMP has an average smaller than zero, presents a negative asymmetry and the kurtosis has a value under 3 which means that the distribution is platkurtosis. Taking into account that the Jarque-Bera test has a value of 4.107962 and the probability is $0.128>0.01$ means that the zero hypothesis is accepted. (figure 2) Statistical correlation tests resulted in the fact that only three of the six independent variables of the model are statistically important. (table 3) As a consequence, the tested regression model shall have the following form:

$C M P=\alpha_{0}+\alpha_{1} \frac{D A T}{K_{P R}}+\alpha_{2} \frac{A I}{A T}+\alpha_{3} \frac{R E}{K_{P R}}$

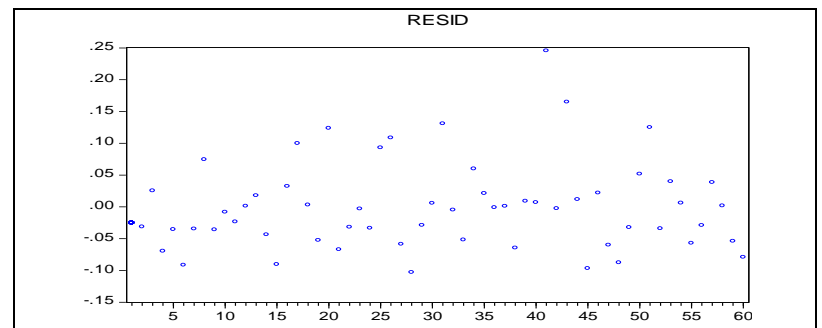

Fig. 1. Residual distribution

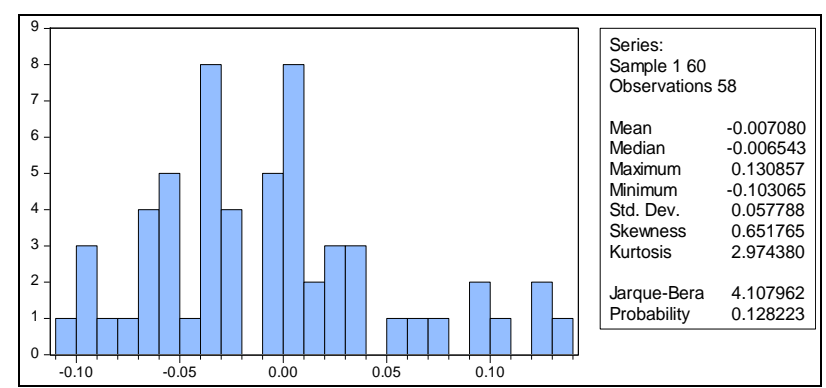

Fig. 2. Histogram - Normality Test

\begin{tabular}{|c|l|}
\hline $\begin{array}{c}\text { Independent } \\
\text { variables }\end{array}$ & $\begin{array}{c}\text { Sign of the dependent variable correlation } \\
\text { with the independent variables }\end{array}$ \\
\hline$L E V=\frac{D A T}{K_{P R}}$ & $\begin{array}{l}\text { + LEV (The leverage rate, presents a positive } \\
\text { corelation reported to the average weighted cost } \\
\text { of the capital) }\end{array}$ \\
\hline$P A I=\frac{A I}{A T}$ & $\begin{array}{l}\text { - PAI (the weight of the assets immobilized in } \\
\text { the total assets, presents a negative corelation } \\
\text { reported to the average weighted cost of the } \\
\text { capital) }\end{array}$ \\
\hline$R O E=\frac{R E}{K_{P R}}$ & $\begin{array}{l}\text { + ROE (return on equity, presents a positive } \\
\text { corelation reported to the average weighted cost } \\
\text { of the capital) }\end{array}$ \\
\hline
\end{tabular}

Tab. 3. Correlation of the dependent variable wit the independent variables

After processing the financial information of the companies presented in the database with the support of the multiple linear regression we may conclude that the results obtained with the help of the regression model reflect the fact that the independent variables taken into consideration explain in a great measure the evolution of the analyzed dependent variable (CMP).

In other terms, the optimal financing structure could be determined by the control on the financial leverage of the enterprise (LEV), on the weight of the immobilized assets (PAI) and on the return on equity (ROE).

\section{VALIDATION OF THE DETERMIANNT FACTORS OF CMP THROUGH THE METHOD OF THE MAIN COMPONENTS ANALYSIS}

The method of main components was used in order to analyse the influence that the independent variables of the regression model have on the weighted average cost of the enterprise capital (CMP).

The analysis used a number of three representative markers (the leverage rate, the weight of the assets immobilized in the total assets, the rate of return on equity) (table 4).

The greater the standard deviation, the more different the companues are judging after that characteristic. In our case, the standard deviation reports bigger values only for the financial leverage (LEV) which means that the companies sample group proposes a small variability space where the structure of causal dependences is not highly complex (table 5).

As expected, there are strong correlations between the analysed variables, which reduces, on the one hand, the individual significance of the latter and, on the other hand, highlights the exitence of informationa redundances:there is a significant quantity of information dissipated into links between variables. Our project proposes both a reduction of dimensionality of the initial causal space and a discharge of these informational 
redundances and this is the reason why we use the method of the main components analysis.

\begin{tabular}{|c|c|c|}
\hline & Average & Standard deviation \\
\hline LEV & 0.036956 & 2.294341 \\
\hline PAI & 0.545021 & 0.201648 \\
\hline ROE & -0.046962 & 0.868111 \\
\hline
\end{tabular}

Tab. 4. Average and standard deviation

\begin{tabular}{|c|c|c|c|}
\hline & LEV & PAI & ROE \\
\hline LEV & 1.000000 & -0.022545 & -0.404623 \\
\hline PAI & -0.022545 & 1.000000 & -0.011761 \\
\hline ROE & -0.404623 & -0.011761 & 1.000000 \\
\hline
\end{tabular}

Tab. 5. Correlation matrix

\begin{tabular}{|c|c|c|c|}
\hline Self value & $\begin{array}{c}\text { \% Total } \\
\text { variation }\end{array}$ & $\begin{array}{c}\text { Cumulatied self } \\
\text { value }\end{array}$ & $\begin{array}{c}\text { \% Cumulatied } \\
\text { variation }\end{array}$ \\
\hline 1.404767 & 46.82555 & 1.404767 & 46.8256 \\
\hline 1.001305 & 33.37685 & 2.406072 & 80.2024 \\
\hline 0.593928 & 19.79760 & 3.000000 & 100.0000 \\
\hline
\end{tabular}

Tab. 6. The values of the correlation matrix

We continue by calculating the values of the correlation matrix (table 6). We want to mention that we are only interested in super-unitary self values, as we think that the useful components in analysis are those main components that are richer in informational content than the original variables.

As it can be observed, there are two own values that are bigger than the unit, therefore we will have two main components. They explain about $80 \%$ of the variability of the initial causal space, meaning that the reduction of the analysed space dimensionality from three to only two variables was done on the expense of a $20 \%$ informational loss, a percentage that can be seen as good. At the same time we notice that the first characteristic synthesize individually no less than $47 \%$ of the information contained by the three initial markers, and thus, it can be used later to build a relevant classification of the enterprises in the sample group of study.

We further determined the factor matrix for the three representative components that resulted. The factor matrix in very important in our analysis because its elements are coefficietns of correlation between the original variables and the main components. As it can be observed, the first main component synthesizes the financial leverage (LEV) and return on equity (ROE) markers, being understood as an important marker of CMP; the second compenent is strongly correlated with weight of the immobilized assets in the total assets (PAI), a fundamental marker to measure CMP. After processing the data in the six independent variables in the regression model, it turned out that only the financial leverage (LEV), the weight of the immobilized assets in the total assets (PAI) and return on equity (ROE) are determinant factors that highly influence the weighted average cost of the enterprise capital.

\section{CONCLUSION}

After processing the financial data, the two methods of econometric analysis (multiple linear regression and main components method) help us see that an optimal structure of the enterprise capital can be achieved on the condition of minimizing the weighted average cost of the capital (CMP), significantly influenced on its turn by the evolution of the financial leverage (LEV), the return on equity (ROE) and the evolution of the weight of the immobilized assets in the total assets (PAI).

The analyses of the capital structure of publicly traded corporations highlights the fact that the main financing resource is represented by the company's own capital and the rest of capitals in corporations coem from external resources, most often bank loans on short and long terms. This analysis highlights the fact that enterprises try to cover the financing necessary especially from their own resources and only when they reached their limit will managers call for external sources.

In the curent financial crisis, which has a great impact on cash flow and ability of entreprises to keep borrowing with rates at the same level as that prevailing before the crisis, it becomes necessary in detail their operations and identify the amount of borrowed capital that can be supported. The companies should not use dept in the absence of some studies on the effects of financial lever on their work, the influence of taxation on the level of borrowing, but also an analysis of capital structure using econometric models to evaluate the cost of capital adjusted for the emerging markets.

Also, as far as the debt structure of publicly traded corporations, representing the object of the study, it is obvious that the management of such enterprises prefer loans with mautrity date of less than one year rather than debts with maturity date longer than onea year.

This tendency of managers of entering into rather short term debts can be explained by the restrictive conditions set by the banks when granting long term loans. In the proces of elaborating this paper we have had in mind the fact that most studies on the subject are taking into account data from developed markwts and for countries like Romania, empirical results do not applay fully. The proposed structure of the work is trying to address key issues involved in obtaining the optimal capital structure.

The fact that it was not found the optimal capital structure could be an indication of the need to recast the original problem.

In conclusion, we can say that the financing structure generally used by Romanian enterprises is in accordance with e the principles of the pecking order theory.

\section{REFERENCES}

[1] Booth, T.; Aivazian, V.; Demirguc-Kunt, A.; Maksimovic, V. (2001) Capital structures in developing countries, Journal of economics, no.LVI, pag.87-130

[2] Fama, E.F.; Jensen, M.C. (1985) Organisational forms and investment decisions, Journal of Financial Economics, no. 14

[3] Harris, M.; Raviv, A. (1990) Capital structure and the information role of debt, The Journal of Finance, no. 2

[4] Myers, S.C. (1984) The Capital Structure Puzzle, The Journal of Finance, no.39, pag.575-592

[5] Narayanan, M.P. (1988) Managerial incentives for short-term results, The Journal of Finance

[6] Vintila, G. (2008) Gestiunea financiara a intreprinderii, Publisher $E D P$, ISBN 973-30-2358-2, Bucharest

[7] Vintilă, G.; Armeanu, D.; Nedelescu, M. (2011) Analysis of the main factors of optimization of long term financing structure of Romanian entreprises, 22 ${ }^{\text {nd }}$ International DAAAM Symposium, November 2011, Vienna, Austria, pag.233-234, ISSN 1726-9679

[8] Wiliamson, S. (1988) Liquidity, banking and bank failures, International Economic Review, vol 25 